\title{
Assessment of Different Lily Types for Suitability for Commercial and Landscaping Use
}

\author{
G. Ashok Kumar ${ }^{1 *}$ and A. Jaya Jasmine ${ }^{2}$ \\ Floriculture Research Station, Tamil Nadu Agricultural University, \\ Thovalai, Tamil Nadu, India \\ *Corresponding author
}

\begin{tabular}{l} 
Ke y w o r d s \\
$\begin{array}{l}\text { Accessions, Flower, } \\
\text { Vegetative and } \\
\text { Thovalai }\end{array}$ \\
Article Info \\
$\begin{array}{l}\text { Accepted: } \\
18 \text { November } 2020 \\
\text { Available Online: } \\
\text { 10 December } 2020\end{array}$ \\
\hline
\end{tabular}

A B S T R A C T

\begin{abstract}
An experiment was carried out for the assessment of different lily types of their performance with respect to growth and flowering during 2017-18 at Floriculture Research Station, Thovalai. The accessions under study showed significant variation for different characters. The experiment was laid out in a randomized block design with 8 treatments and each treatment replicated thrice. Among the lily accessions highest leaf growth has been observed in KN - 5 (Pudhugramam) with 25 leaves followed by $\mathrm{KN}$ - 4 (Thenthamaraikulam) with 24 leaves. Maximum leaf length $(31.30 \mathrm{~cm})$ and leaf breadth $(31.70 \mathrm{~cm}$ ) was observed in $\mathrm{KN}-2$ (Erachakulam). In flowering traits, among the lily accessions, the highest flower stock length $(120 \mathrm{~cm})$ was recorded in $\mathrm{KN}-1$ (Bhemenari) and maximum number of petals $(58)$, petal width $(3.10 \mathrm{~cm})$ and flower weight $(32 \mathrm{~g})$ was observed in $\mathrm{KN}-4$ (Thenthamaraikulam) and petal length $(8.60 \mathrm{~cm})$ was observed in $\mathrm{KN}$ 2 (Erachakulam). In this study, both the vegetative and flowering characters showed wider variation. The selected accessions can be used both for commercial and landscaping use under Tamil Nadu condition, also with proper management practices good quality flowers can be produced from these accessions. Hence, these accessions may be useful for further breeding program.
\end{abstract}

\section{Introduction}

Flowers are symbol of beauty, love and tranquillity; they form the soul of garden and convey the message of nature to mankind. Lilium is one of the horticultural most important genera for cut flower and pot plant production. The genus Lilium of the family Liliaceae comprises more than 80 species and these are divided into seven sections (Comber, 1949). Northern hemisphere, mainly Asia,
North America and Europe, especially China, Nepal, Korea and Japan are the gene centres of this genus around the world. It is one of the six major genera of flower bulbs produced worldwide (Hertogh and Le Nard, 1993). It is a species of great economic importance in production and commercialization of cut flower in the international market (Jimenez et $a l ., 2012$ ). Due to its size, beauty and longevity Lilium is one of the ten most superior cut flowers in the world (Thakur et al., 2005). Due 
to their large and attractive flowers having capacity to rehydrate after a long transportation, popularity of Lilium is gaining fast in our country. The cultivars of genus Lilium are highly appreciated by the horticulturists for their outstanding range of colour, fragrance and adaptability to several environmental conditions (Bahr and Compton, 2004). Lilium deserves to be called the aristocrat of the plant world. Lilies can be used for informal planting in grassland or among orchard trees, along crocuses, bluebells and tulip to create flower meadows (Beck, 2010). They can be planted in lines along formal paths (Dilon, 2010). Lilium hybrids have a wide range of colours and shape which are produced from interspecific hybridization. The popularity of these hybrids, especially Asiatic and oriental types is increasing both as cut flower and pot plant (Lian et al., 2003).

In Tamil Nadu, Lilium is gaining popularity both as cut flower as well as garden plants. However, almost all the cut flowers of Lilium available in the florists' shop are being procured from Bangalore, Pune and other places of the country. It has been observed that Asiatic lily varieties/hybrids grown as garden plants by some amateurs in Tamil Nadu and other urban areas of the state are coming up well with a wide range of size, shape and colour. Although the agro climatic condition of the state is quite favourable for this flower crop, its commercial cultivation has not yet been started by the flower growers due to lack of knowledge about its production technology and unavailability of quality planting materials. Among several factors influencing growth, yield and quality of flowers, including Lilium improved varieties / hybrids play significant roles which need proper evaluation for their performance under local agro climatic condition.Hence, a systematic study was presently undertaken in assessment of different lily types for suitability for commercial and landscaping use.

\section{Materials and Methods}

This study was carried out during 2017-2018 at Floriculture Research Station, Thovalai. The experiment pertaining the assessment of different lily types for suitability for commercial and landscaping use. Eight lily accession have been collected and established in the pond. During this year silpaulin lined ponds have also been established and planting of lilies have been done. Maximum survival of $95 \%$ of lily was observed.The experiment was laid out in a Randomized Block Design (RBD) with 8 treatments. The observations on vegetative parameters likeleaf length, leaf breadth, number of leaves, leaf stock lengthand the floral parameters i.e.flower stock length, number of sepals, number of whorls, number of petals, petals length, petals width, number of anthers, number of flowers and flowers weightwere taken. The experimental data were analysed statistically by ANOVA (Analysis Of Variance) technique (Panse and Sukhatme, 1985). The flower colour and survival percentage is presented in Table 1.

\section{Results and Discussion}

\section{Vegetative characters}

The data pertaining to the vegetative characters like flower colour, leaf length, leaf breadth, number of leaves and leaf stock length is presented in Table 1 and 2. Another vegetative traits like leaf colour, leaf hairs, leaf margin and leaf netting was presented in Table 3. Significant differences were observed in leaf length, leaf breadth, number of leaves and leaf stock length at the end of vegetative stage.

The flower colour of accessions like $\mathrm{KN}-1$ Bhemenaritype (White with Pink tip), KN - 2 Erachakulamtype (Pink), KN - 3 Layamtype (Dark red), KN - 4 Thenthamaraikulamtype 
(Pale Yellow), KN - 5 Pudhugramamtype (white with blue tip), KN - 6 Nagercoiltype (Violet), KN - 7 Salemtype (Pure Yellow) and KN - 8 Yercaudtype (Peach). Among the lily accessions maximum leaf growth has been observed in $\mathrm{KN}$ - 5 (Pudhugramam) with 25 leaves followed by $\mathrm{KN}$ - 4 (Thenthamaraikulam) with 24 leaves while the least was observed in KN - 7 (Salem) with 5 leaves. Maximum leaf length $(31.30 \mathrm{~cm})$ and leaf breadth $(31.70 \mathrm{~cm})$ was observed in $\mathrm{KN}$ - 2(Erachakulam) while least leaf length $(16.80 \mathrm{~cm})$ and leaf breadth $(16.00 \mathrm{~cm})$ was observed in $\mathrm{KN}-8$ (Yercaud). The maximum leaf stock length $(99.20 \mathrm{~cm})$ was recorded in $\mathrm{KN}$ - 3 (Layam) and minimum leaf stock length $(77.80 \mathrm{~cm})$ was recorded in $\mathrm{KN}-4$ (Thenthamaraikulam). Similar variations in leaf width of Asiatic lilium varieties were also recorded by Pandey et al., (2008) and Natraj et al.(2014). Similarly variation in vegetative traits of lilium has been reported by Mishra (1997), Naiket al.(2006), Barik (2013), Singh et al., (2016), Barik andMohanty (2015) and Dekaet al., $(2010)^{[6]}$. Differences in vegetative characters of different cultivars of lilium may be due to varied growth rates and their genetic potential resulted in variation in phenotypic expression. Kim et al., (2013) and Pandey et al., (2008) reported similar result of vegetative growth in Asiatic hybrid lily.

Table.1 Survey and collection of lily types under Thovalai conditions

\begin{tabular}{|c|l|c|c|}
\hline Acc. No & \multicolumn{1}{|c|}{ Place of collection } & Flower colour & Survival (\%) \\
\hline KN - 1 & Bhemenari & White with Pink tip & $90 \%$ \\
\hline KN - 2 & Erachakulam & Pink & $80 \%$ \\
\hline KN - 3 & Layam & Dark red & $90 \%$ \\
\hline KN - 4 & Thenthamaraikulam & Pale Yellow & $95 \%$ \\
\hline KN - 5 & Pudhugramam & White with Blue tip & $90 \%$ \\
\hline KN - 6 & Nagercoil & Violet & $80 \%$ \\
\hline KN - 7 & Salem & Pure Yellow & $50 \%$ \\
\hline KN - 8 & Yercaud & Peach & $60 \%$ \\
\hline
\end{tabular}

Table.2 Vegetative parameters of lily types under Thovalai conditions

\begin{tabular}{|r|l|c|c|c|c|}
\hline Acc. No. & Place of collection & $\begin{array}{c}\text { Leaf length } \\
(\mathbf{c m})\end{array}$ & $\begin{array}{c}\text { Leaf breadth } \\
(\mathbf{c m})\end{array}$ & $\begin{array}{c}\text { No of } \\
\text { Leaves }\end{array}$ & $\begin{array}{c}\text { Leaf stock } \\
\text { length } \mathbf{( c m})\end{array}$ \\
\hline KN - 1 & Bhemenari & 22.00 & 18.50 & 16 & 83.50 \\
\hline KN - 2 & Erachakulam & 31.30 & 31.70 & 20 & 92.00 \\
\hline KN - 3 & Layam & 21.00 & 18.50 & 20 & 99.20 \\
\hline KN - 4 & Thenthamaraikulam & 22.20 & 23.20 & 24 & 77.80 \\
\hline KN - 5 & Pudhugramam & 21.30 & 19.00 & 25 & 80.00 \\
\hline KN - 6 & Nagercoil & 21.80 & 20.50 & 17 & 85.50 \\
\hline KN - 7 & Salem & 21.50 & 21.60 & 5 & 82.30 \\
\hline KN - 8 & Yercaud & 16.80 & 16.00 & 17 & 83.50 \\
\hline & Mean & $\mathbf{2 2 . 2 4}$ & $\mathbf{2 1 . 1 2}$ & $\mathbf{1 8}$ & $\mathbf{8 5 . 4 7}$ \\
\hline & SEd & $\mathbf{0 . 6 7}$ & $\mathbf{0 . 9 0}$ & $\mathbf{2 . 5 0}$ & $\mathbf{2 . 6 7}$ \\
\hline & CD $(\mathbf{0 . 0 5})$ & $\mathbf{0 . 1 3} * *$ & $\mathbf{0 . 1 8 * *}$ & $\mathbf{0 . 5 0} * *$ & $\mathbf{0 . 5 3} * *$ \\
\hline
\end{tabular}


Table.3 Morphological parameters in Lily

\begin{tabular}{|c|l|l|l|l|l|}
\hline Acc. No. & \multicolumn{1}{|c|}{ Name of lily } & \multicolumn{1}{|c|}{ Leaf colour } & Leaf hairs & Leaf margin & $\begin{array}{c}\text { Leaf } \\
\text { netting }\end{array}$ \\
\hline KN - 1 & Bhemenari & Green on both sides & Absent & Serrated & Absent \\
\hline KN - 2 & Erachakulam & $\begin{array}{l}\text { Greenish red on both } \\
\text { sides }\end{array}$ & Absent & Serrated & Present \\
\hline KN - 3 & Layam & Deep red on both sides & Present & Serrated & Present \\
\hline KN - 4 & Thenthamaraikulam & $\begin{array}{l}\text { Dark green on upper side } \\
\text { and dark brown on lower } \\
\text { side }\end{array}$ & Absent & Entire & Absent \\
\hline KN - 5 & Pudhugramam & $\begin{array}{l}\text { Dark green on upper side } \\
\text { and light Maroon on } \\
\text { lower side }\end{array}$ & Absent & Serrated & Present \\
\hline KN - 6 & Nagercoil & $\begin{array}{l}\text { Dark green on upper side } \\
\text { and Maroon on lower } \\
\text { side }\end{array}$ & Absent & Serrated & Present \\
\hline KN - 7 & Salem & $\begin{array}{l}\text { Green on upper side and } \\
\text { light brown on lower side }\end{array}$ & Absent & Entire & Absent \\
\hline KN - 8 & Yercaud & $\begin{array}{l}\text { Green on upper side and } \\
\text { Maroon on lower side }\end{array}$ & Absent & Entire & Absent \\
\hline
\end{tabular}

Table.4 Flower characters of lily

\begin{tabular}{|c|c|c|c|c|c|c|c|c|c|}
\hline Acc. No. & $\begin{array}{c}\text { Flower } \\
\text { Stalk } \\
\text { length (cm) }\end{array}$ & $\begin{array}{c}\text { No. of } \\
\text { Sepals }\end{array}$ & $\begin{array}{c}\text { No. of } \\
\text { Whorls }\end{array}$ & $\begin{array}{c}\text { No. of } \\
\text { Petals }\end{array}$ & $\begin{array}{c}\text { Petals } \\
\text { length } \\
\text { (cm) }\end{array}$ & $\begin{array}{c}\text { Petals } \\
\text { width } \\
\text { (cm) }\end{array}$ & $\begin{array}{c}\text { No. of } \\
\text { Anthers }\end{array}$ & $\begin{array}{c}\text { No. of } \\
\text { flower }\end{array}$ & $\begin{array}{c}\text { Flower } \\
\text { weight } \\
\text { (g) }\end{array}$ \\
\hline KN - 1 & 120.00 & 3 & 3 & 21 & 6.30 & 2.40 & 30.00 & 7 & 21 \\
\hline KN - 2 & 85.00 & 4 & 5 & 33 & 8.60 & 2.50 & 62.00 & 5 & 22 \\
\hline KN - 3 & 93.00 & 4 & 3 & 28 & 6.00 & 2.00 & 32.00 & 7 & 18 \\
\hline KN - 4 & 88.50 & 2 & 5 & 58 & 8.30 & 3.10 & 65.00 & 10 & 32 \\
\hline KN - 5 & 79.00 & 4 & 3 & 24 & 6.10 & 1.80 & 19.00 & 19 & 16 \\
\hline KN - 6 & 85.50 & 4 & 3 & 28 & 4.50 & 1.60 & 88.00 & 8 & 18 \\
\hline KN - 7 & 83.00 & 3 & 3 & 31 & 4.10 & 1.50 & 90.00 & 3 & 17 \\
\hline KN - 8 & 86.00 & 4 & 4 & 40 & 6.80 & 2.00 & 38.00 & 4 & 19 \\
\hline Mean & $\mathbf{9 0 . 0 0}$ & $\mathbf{3 . 5 0}$ & $\mathbf{3 . 6 3}$ & $\mathbf{3 2 . 8 7}$ & $\mathbf{6 . 3 4}$ & $\mathbf{4 . 3 6}$ & $\mathbf{5 3 . 0 0}$ & $\mathbf{7 . 8 8}$ & $\mathbf{2 0 . 3 8}$ \\
\hline SEd & $\mathbf{4 . 6 2}$ & $\mathbf{0 . 2 5}$ & $\mathbf{0 . 2 5}$ & $\mathbf{4 . 6 2}$ & $\mathbf{0 . 5 6}$ & $\mathbf{2 . 3 1}$ & $\mathbf{8 . 8 7}$ & $\mathbf{2 . 0 0}$ & $\mathbf{2 . 0 0}$ \\
\hline CD $(\mathbf{0 . 0 5})$ & $\mathbf{0 . 9 2} * *$ & $\mathbf{0 . 0 5} * *$ & $\mathbf{0 . 0 5} * *$ & $\mathbf{0 . 9 2} * *$ & $\mathbf{0 . 1 1} * *$ & $\mathbf{0 . 4 6} * *$ & $\mathbf{1 . 7 7} * *$ & $\mathbf{0 . 4 0}$ & $\mathbf{0 . 4 0}$ \\
\hline
\end{tabular}

\section{Flower characters}

The data pertaining to the flower characters like flower stock length, number of sepals, number of whorls, number of petals, petals length, petals width, number of anthers, number of flowers and flowers weight is presented in Table 4. Significant differences were observed in flower stock length, number of sepals, number of whorls, number of petals, petals length, petals width, number of anthers, number of flowers and flowers weight at the flowering stage.

Among the lily accessions, the highest flower stock length $(120 \mathrm{~cm})$ was recorded in $\mathrm{KN}-1$ 
(Bhemenari) and lowest $(79 \mathrm{~cm})$ was recorded in $\mathrm{KN}$ - 5 (Pudhugramam). Maximum number of petals (58), petal width $(3.10 \mathrm{~cm})$ and flower weight (32 g) was observed in $\mathrm{KN}-4$ (Thenthamaraikulam) and petal length (8.60 cm) was observed in $\mathrm{KN}$ - 2 (Erachakulam). Maximum number of anthers (90) was recorded in KN - 7 (Salem) and number of flowers (19) was recorded in $\mathrm{KN}-5$ (Pudhugramam). The least petals length (4.10 $\mathrm{cm})$, petals width $(1.50 \mathrm{~cm})$ and minimum number of flowers (3) was recorded in $\mathrm{KN}-7$ (Salem). The flower characters showed wider variation among the accessions. Similar variation among the cultivar traits was also reported by Kumar et al., (2011), Sindhu and Singh (2012) in Lilium. Maximum number of flower per plant is an important parameter of Lilium crops are always preferred which fetch maximum price in market. In present study significant variation in number of flower was observed due to different cultivars tried. Similar trend of flower character has been observed by Negi et al., (2014), Deka et al., (2010) and Srinivas (2002) in lilium cultivar. Wide variation in flower traits due to cultivars has also been reported by Dhiman (2003) ${ }^{[7]}$ and Singh et al., (2016). Pandey et al., (2012) reported the same variation in gladiolus.

It is concluded that the variation in accessions may be due to genetic and environmental interaction. The selected accessions can be used both for commercial and landscaping use under Tamil Nadu condition, also with proper management practices good quality flowers can be produced from these accessions. Hence, these accessions may be useful for further breeding program.

\section{References}

Bahr, L.R. and Compton, M.E. (2004). Competence forin vitro bulb regeneration among eight Lilium genotypes. Hort Sci., 39 (1): 127-129
Barik, D. 2013. Comparative performance of Asiatic hybrid lily varieties under open and protected environment. M.Sc (Ag) thesis, submitted to Orissa University of Agriculture and Technology, Bhubaneswar.

Barik, D. and Mohanty, C.R. (2015). Evaluation of Asiatic hybrid lily varieties under Bhubaneswar condition. Asian J. Hort., 10(2): 194-200.

Beck, C. (2010). Yorkshire moreish. Garden Illustrated, 161, May, pp. 52-59

Comber, H. (1949). A new classification of the genus Lilium. Lily year book, Royal Hort. Soc., London, 13: 86-105.

Deka, Rajiv Kumar, Bidyut, C. and Patel, V. V. (2010). Evaluation of Asiatic Liliumunder sub-tropical mid hills of Meghalaya. J. Ornam. Hort., 13(4):257260.

Dhiman, M.R. (2003). Evaluation of hybrid lily under Kullu conditions. J. Ornam. Hort., 6 (2): 154-155.

Dilon, H. (2010). A plants man's paradise. Garden Illustrated. 164, Aug., 2010, pp. 84-88

Hertogh and Le Nard (1993). (Eds). The physiology of flower bulbs, Amsterdam, The Netherlands; Elsevier

Jimenez, S., Plaza, B.M., Segura, M.L., Contreras, J.I. and Lao, T.M. (2012). Peat substrate reuse in Lilium "Haveltia" crop. Commun. Soil Sci. \& Plant Analysis, 43:243-250.

Kim, M.J., Hong, S.J. and Kim, H.K. (2013). Effect of bulblets size Oriented from tissue culture on growth and bulb enlargement of Lilium Oriental Hybrids grown in highlands. Kor. J. Hort. Sci. Tech. 31(2): 165-172.

Kumar, R., Patel, V., Verma, D., Bidyut, C., Singh, S. and Sindhu, S. (2011). Evaluation of Asiatic lilium under subtropical mid hills of Meghalaya. Adv. Res. J. of C. Improv. 2(2): 257- 259.

Lian, M.L., Chakrabarty, D. and Paek, K.Y. 
(2003). Growth of oriental hybrid 'Casablanca' bulblet using bioreactor culture. Sci. Hort., 97: 41-48

Mishra, H.P. (1997). Performance of gladiolus genotypes under calcareous soil for North Bihar. Indian J. Hort., 14(1): 77-92.

Naik, B.H., Chauhan, N., Patil, A.A., Patil, V.S. and Patil, B.C. 2006. Comparative performance of gerbera cultivars under naturally ventilated polyhouse. Journal of ornamental horticulture, 9(3): 2004207.

Nataraj, S.K., Chandrashekar, S.Y., Hemal, N.B. and Latha, S. 2014. Performance of Asiatic lilium hybrid under hill zone of Karnataka. Third International symposium on the genus lilium, Zhangzhou, China. April 1-3,68.

Negi, R., Kumar, S. and Dhiman, S.R. (2014). Evaluation of lilium (Lilium spp.) Cultivars for low hills of Himachal Pradesh. Ind. J. Sci. Res. and Tech. 2(4): 8-10.

Pandey, R.K., Bhat, Deep Ji, Dogra, Sheetal, Singh, Arvinder, Laishram, Nomita and Jamwal, Shivani (2012). Evaluation of gladiolus cultivars under subtropical conditions of Jammu. Internat. J. Agric. Sci., 8(2): 518-522.

Pandey, R.K., Dogra, Sheetal, Sharma, J.P. and Jamwal, Shivani (2008). Evaluation of Asiatic hybrid lily cultivars under subtropical conditions of Jammu region. J. Plant Sci. \& Res., 24 (2): 213-214.

Panse, U. G. and P. V. Sukhatme. 1985. Statistical Methods for Agricultural Workers. 4th ed, ICAR publication, New Delhi,India.

Sindhu, S.S. and Singh, J.P. (2012). Evaluation of Lilium cultivars under Northern plains. Internat. J. Agric. Sci., 8(2): 460-461.

Singh, M. K., Kumar, S., Ram, Raja and Prasad, R. (2016). Effect of size of bulb, growing conditions and depth of planting on flower and bulb production of Asiatic hybrid lily (Liliumspp) cv. Brunello. Ind. J. of agri. Sci. 86(3): 3913.

Srinivas, M. (2002). Response of Asiatic lilies to open cultivation. Abstract, Natioal Symposium on Indian Floriculture in the New Millennium. Feb.25-27, 50-51.

Thakur, R., Sood, A., Nagar, P. K., Pandey, S., Sobti, R.C. and Ahuja, P.S. (2005). Regulation of growth of Lilium plantlets in liquid medium by application of paclobutrazol or ancymidol for its amenability in a bioreactor system: growth parameters. Plant Cell Rep., 25: $382-391$.

\section{How to cite this article:}

Ashok Kumar, G. and Jaya Jasmine, A. 2020. Assessment of Different Lily Types for Suitability for Commercial and Landscaping Use. Int.J.Curr.Microbiol.App.Sci. 9(12): 27772782. doi: https://doi.org/10.20546/ijcmas.2020.912.331 